\title{
Unusual Property of Prion Protein Unfolding in Neutral Salt Solution
}

\author{
P. K. Nandi, ${ }^{*} \neq$ E. Leclerc, ${ }^{\S}$ and D. Marc $\$$ \\ Pathologie Infectieuse et Immunologie, Institut National de la Recherche Agronomique, 37380 Nouzilly, France, and \\ Department of Immunology, Scripps Research Institute, La Jolla, California 92037
}

Received March 27, 2002; Revised Manuscript Received July 5, 2002

\begin{abstract}
The unfolding of cellular prion protein and its refolding to the scrapie isoform are related to prion diseases. Studies in the literature have shown that structures of proteins, either acidic or basic, are stabilized against denaturation by certain neutral salts, for example, sulfate and fluoride. Contrary to these observations, the full-length recombinant prion protein (amino acid residues 23-231) is denatured by these protein structure stabilizing salts. Under identical concentrations of salts, the structure of the sheep prion protein, which contains a greater number of glycine groups in the $\mathrm{N}$-terminal unstructured segment than the mouse protein, becomes more destabilized. In contrast to the full-length protein, the C-terminal 121-231 prion protein fragment, consisting of all the structural elements of the protein, viz., three $\alpha$-helices and two short $\beta$-strands, is stabilized against denaturation by these salts. We suggest that an increase in the concentration of the anions on the surface of the prion protein molecule due to their preferential interaction with the glycine residues in the N-terminal segment destabilizes the structure of the prion protein by perturbing the prion helix 1 which is the most soluble of all the protein $\alpha$-helices reported so far in the literature. The present results could be relevant to explain the observed structural conversion of the prion protein by anionic nucleic acids and sulfated glycosaminoglycans.
\end{abstract}

Prion diseases which cause lethal neurological disorders in human and animals are both genetic and infectious (13 ). Hereditary human prion diseases such as familial Creutzfeldt Jakob disease and Gertsmann-Straussler-Scheinker have been linked to specific mutations in the prion protein gene. Further, the interspecies transmission of the disease, viz., the transmission of bovine spongiform encephalopathy to zoo animals, cats, and humans causing new variants of prion disease, is of serious medical, economic, and social implications. It has been suggested that the disease is caused by a posttranslational modification of soluble cellular prion protein $\operatorname{PrP}^{\mathrm{C}},{ }^{1}$ which is rich in $\alpha$-helix, to its $\beta$-sheet-rich insoluble scrapie isoform $\operatorname{PrP}^{\mathrm{Sc}}$. Both $\operatorname{PrP}^{\mathrm{C}}$ and $\mathrm{PrP}^{\mathrm{Sc}}$ are glycoproteins consisting of 208 amino acids (residues 23231) which remain attached to the cell surface by a glycosylphosphatidylinositol anchor and contain one disulfide bridge linking residues 179 and $214(1,4)$. $\mathrm{PrP}^{\mathrm{Sc}}$ has been suggested to convert $\operatorname{PrP}^{\mathrm{C}}$ to its like and spontaneously forms oligomers and polymers with amyloid-like characteristics which are believed to cause the disease and its transmission $(1-5)$.

Understanding of the structural, biochemical, and biophysical properties of cellular prion protein in solution has mostly been obtained from the studies of the full-length recombinant prion protein and its different fragments $(6-13)$. The three-

* Corresponding author. Tel: (33) 2474278 87. Fax: (33) 247 4277 79. E-mail: nandi@tours.inra.fr.

¥ Institut National de la Recherche Agronomique.

§ Scripps Research Institute.

${ }^{1}$ Abbreviations: $\operatorname{PrP}^{\mathrm{C}}$, cellular prion protein; $\mathrm{PrP}^{\mathrm{SC}}$, scrapie isoform; MoPrP, mouse prion protein; ShPrP, sheep prion protein; CD, circular dichroism; $T_{\mathrm{m}}$, temperature of midpoint of structural transition of protein. dimensional structures of the recombinant full-length murine, hamster, and human prion proteins and their fragments have been obtained from NMR and crystallographic studies ( 1 , $6-16)$. The highly positively charged N-terminal segment comprising residues $23-125$ of the protein is flexibly disordered. The N-terminal segment contains four octapeptide repeats, PHGG(G/S)WGQ (between residues 60 and 93), and a homologous sequence lacking a histidine residue PQGGGTWGQ (between residues 52 and 60) $(1,17,18)$. The globular C-terminal fragment 121-231 contains three $\alpha$-helices and two $\beta$-strands $(6-13)$. The hydrophilicity and charge distribution make the first prion protein $\alpha$-helix unique among all naturally occurring protein $\alpha$-helices (19). Molecular dynamics simulation indicates that electrostatic interaction in general and salt bridges in particular play an important role in prion protein stability $(6,11,13,20)$. The prion protein has been shown to be involved in copper metabolism and signal transduction $(21,22)$.

Interaction of the recombinant prion proteins with various biologically relevant molecules has been reported $(23,24)$. Mouse recombinant full-length prion protein, $\operatorname{MoPrP}(23-$ 231 ), polymerizes to amyloid-like fibers in the presence of nucleic acids of different compositions (23). DNA can also modulate the aggregating properties of prion protein (25). Interaction between prion protein and nucleic acid also leads to the formation of ordered nucleic acid aggregates and condensed nucleic acid globules which spontaneously dissociate to individual nucleic acid molecules (26). These properties of the prion protein-nucleic acid complex have lead to our demonstration that prion protein can play a role in nucleic acid metabolism $(27,28)$. The unstructured $\mathrm{N}$-terminal segment has been found to be responsible for the functional properties of the prion protein (28). 
The denaturation of the recombinant full-length prion protein and its $\mathrm{N}$ - and C-terminal fragments, 90-231 and 121-231, respectively, has been studied at different $\mathrm{pHs}$ and in the presence of denaturants to characterize the solution and structural properties of the prion protein $(29-36)$.

Electrolytes have been used to understand the contribution of different types of noncovalent forces toward the stability and structural properties of proteins in solution $(37,38)$. We report here the studies on the secondary structures and thermal stabilities against denaturation of full-length mouse and sheep prion proteins, the C-terminal MoPrP(121-231) fragment, and a basic protein lysozyme to demonstrate an unique structural destabilization property of the prion protein in salt solutions.

\section{EXPERIMENTAL PROCEDURES}

The full-length mouse and sheep recombinant prion proteins and the $\mathrm{C}$-terminal MoPrP (121-231) fragment were isolated by the procedures already described $(6,31,34)$. The ovine protein, ShPrP, used was the normal ARR variant $\left(\right.$ Ala ${ }^{136} \mathrm{Arg}^{154} \mathrm{Arg}{ }^{171}$ ). Sheep homozygous for the ARR allele are resistant to scrapie (34). Circular dichroism measurements were carried out in $100 \mathrm{mM}$ Tris-HCl, pH 7.5, in a JASCO 710 spectropolarimeter equipped with a JASCO Pelletier temperature control system after 15 min equilibration in respective salt solutions. The concentrations used for the fulllength proteins, the prion protein fragment, and lysozyme were 5,8 , and $14 \mu \mathrm{M}$, respectively. The spectra were recorded between 300 and $200 \mathrm{~nm}$ and presented here between 260 and $200 \mathrm{~nm}$. The stability of the prion proteins and the protein fragment in different electrolytes has been determined by thermal denaturation studies. The protein solution was heated at the rate of $1{ }^{\circ} \mathrm{C} / \mathrm{min}$, and the $\mathrm{CD}$ values were measured at $222 \mathrm{~nm}$ in a cell of $1 \mathrm{~mm}$ path length. Thermal denaturation data obtained from experiments were analyzed with a JASCO protein denaturation program based on two-state structural transitions.

Spectrofluorometric titrations of the tryptophan groups of proteins and $N$-acetyltryptophan ethyl ester were carried out in a JASCO spectrofluorometer FP- 770 at $20^{\circ} \mathrm{C}$ by exciting the samples at $280 \mathrm{~nm}$ and measuring the emission at 350 nm.

\section{RESULTS}

Secondary Structure. The effects of various concentrations of $\mathrm{Na}_{2} \mathrm{SO}_{4}$ on the $\mathrm{CD}$ spectra of the mouse full-length recombinant prion protein are shown in Figure 1a. The intensity of the $\mathrm{CD}$ values decreases and shows a dependence on salt concentration. The relative shapes of the spectra appear to change. This indicates that the percentage of the residues located in the secondary structure probably decreases or new type of secondary structure is formed in $\mathrm{Na}_{2} \mathrm{SO}_{4}$ solutions. Sodium chloride reduces the CD intensity, but the effects are significantly less at the same molar concentrations of $\mathrm{Na}_{2} \mathrm{SO}_{4}$ (not shown). The effect of these salts on the fulllength sheep recombinant prion protein also does not influence significantly the overall shape of the protein $\mathrm{CD}$ spectra (not shown).

A comparison of the CD spectra in the far- and near-UV region of the full-length mouse prion protein and its C-terminal segment shows that the percentage of residues located in regular secondary structures is higher in the
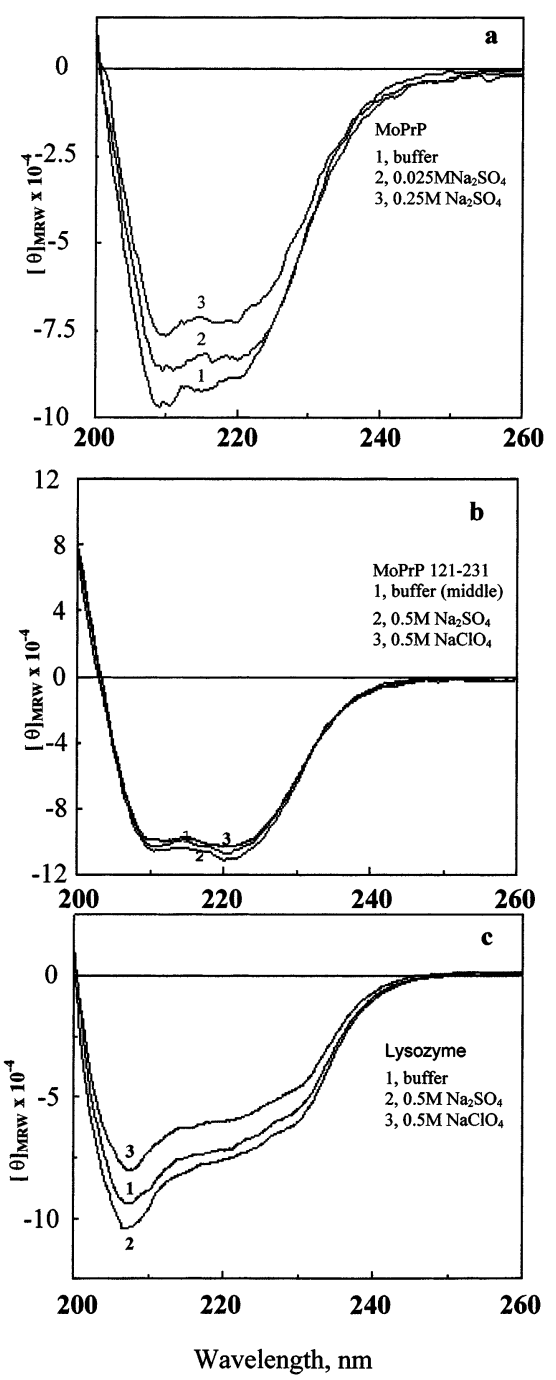

FIGURE 1: Circular dichroism spectra of the full-length mouse prion protein, $\operatorname{MoPrP}(23-231)(a)$, the C-terminal prion protein fragment, MoPrP(121-231) (b), and lysozyme (c), in buffer and different salt solutions. Buffer is $0.1 \mathrm{M}$ Tris- $\mathrm{HCl}, \mathrm{pH} 7.5$. (a) 1 , buffer; 2 and 3, 0.025 and $0.25 \mathrm{M} \mathrm{Na}_{2} \mathrm{SO}_{4}$, respectively; (b) 1, buffer; 2 and 3, $0.5 \mathrm{M} \mathrm{Na}_{2} \mathrm{SO}_{4}$ and $\mathrm{NaClO}_{4}$, respectively. For clarity, the CD spectrum in $0.5 \mathrm{M} \mathrm{NaCl}$ has not been shown, but it is practically superimposable on the protein spectrum in buffer. (c) 1 , buffer; 2 and 3, spectra in $0.5 \mathrm{M} \mathrm{Na}_{2} \mathrm{SO}_{4}$ and $\mathrm{NaClO}_{4}$, respectively. The effect of $0.5 \mathrm{M} \mathrm{NaCl}$ on the protein (not shown) results in an intensity increase which is smaller than the effect of $\mathrm{Na}_{2} \mathrm{SO}_{4}$.

fragment and that the structure of the $\mathrm{C}$-terminal domain is retained in the full-length protein. The $\mathrm{N}$-terminal 23-120 segment is not significantly involved in tertiary structure formation (6). The effect of $\mathrm{Na}_{2} \mathrm{SO}_{4}$ on the circular dichroism pattern on the C-terminal fragment is different from its effect on the full-length protein (Figure 1b). In $0.5 \mathrm{M} \mathrm{Na}_{2} \mathrm{SO}_{4}$ solution, a small increase in the intensity of the $\mathrm{CD}$ signal is observed with a marginal increase of the $\alpha$-helical structure compared to the values in salt-free buffer. The effect on the $\mathrm{CD}$ spectra of the protein fragment in $0.25 \mathrm{M} \mathrm{Na}_{2} \mathrm{SO}_{4}$ solution is even smaller, and $0.5 \mathrm{M} \mathrm{NaCl}$ does not change the spectral pattern compared to buffer (not shown). In 0.5 $\mathrm{M} \mathrm{NaClO}$ solution there is a reduction of the $\mathrm{CD}$ spectral intensity of the protein fragment, indicating a reduction in the secondary structural content of the fragment (Figure 1b).

The protein lysozyme, like prion protein, is basic and can polymerize to form amyloid (39). The shape of the CD 
spectra of lysozyme in buffer is different from those of the full-length prion protein and the protein fragment. The CD intensity of lysozyme at $208 \mathrm{~nm}$ is more pronounced than the value at $220 \mathrm{~nm}$ (Figure 1c). In the presence of salts, the shape of the CD spectra does not change although the overall $\mathrm{CD}$ intensity throughout the spectral range increases in $\mathrm{NaCl}$ and $\mathrm{Na}_{2} \mathrm{SO}_{4}$ solutions. The extent of increase in the $\mathrm{CD}$ signal in these salt solutions is more pronounced than what is observed for the C-terminal prion protein fragment. The $\mathrm{CD}$ intensity of lysozyme in $\mathrm{NaClO}_{4}$ solution decreases to a larger extent than observed for the prion protein fragment in perchlorate solution.

Thermal Stability. Since the starting of the CD values of the proteins in buffer and salt solutions before and after the thermal denaturation (Figure 1a and Figure 2a, inset) varied, normalized transition curves have been presented to demonstrate the thermal denaturation properties of the proteins in different salt solutions. The results show that, for the fulllength $\operatorname{MoPrP}(23-231)$, the midpoint of the thermal denaturation, $T_{\mathrm{m}}$, occurs at $70{ }^{\circ} \mathrm{C}$ in the experimental buffer (Figure 2a). In the presence of $\mathrm{Na}_{2} \mathrm{SO}_{4}$ the temperature of thermal denaturation decreases, and the effect increases with the increase in the concentration of the salt (Figure 2a). Lowering of the thermal transition temperature, albeit to a smaller extent, occurs also in the presence of $\mathrm{NaCl}$ (Table 1). The results indicate that these salts destabilize the structure of the mouse recombinant prion protein.

The thermal denaturation curves of sheep prion protein in the salt solutions are shown in Figure $2 b$. This protein, like the mouse protein, has a $T_{\mathrm{m}}$ value of $70^{\circ} \mathrm{C}$ in $0.1 \mathrm{M}$ Tris buffer. The addition of salts also destabilizes the native sheep prion protein structure. It can be seen from the Figure 2a,b that the lowering of the $T_{\mathrm{m}}$ of the sheep prion protein is greater in the presence of the same concentration of the salts compared to what is observed for mouse prion protein. The results also show that, at the same molar concentration $(0.25$ $\mathrm{M})$, sulfate destabilizes the prion protein structures $\left(T_{\mathrm{m}}, 55^{\circ}\right)$ more than $\mathrm{NaCl}\left(59^{\circ} \mathrm{C}\right)$ or $\mathrm{NaF}\left(65^{\circ} \mathrm{C}\right)$ as shown in Figure $2 \mathrm{c}$ and in Table 1. At higher concentrations of $\mathrm{Na}_{2} \mathrm{SO}_{4}$, the protein solution became spontaneously turbid, which prevented structural or denaturation studies. The destabilization of the sheep prion protein in the presence of phosphate is also observed; e.g., $T_{\mathrm{m}}$ values in 0.035 and $0.1 \mathrm{M}$ phosphate buffer, $\mathrm{pH} 7.5$, are 63 and $61{ }^{\circ} \mathrm{C}$, respectively (Figure 2c and Table 1). The effects of $\mathrm{NaClO}_{4}$, a denaturing salt for all proteins, on the structural stability of the full-length proteins could not be carried out due to the turbidity of the solutions even in the presence of much lower concentrations of the salt $(<0.01 \mathrm{M})$. A comparison of the effects of sodium sulfate and sodium chloride on these two prion proteins is presented in Figure 3.

The midpoint of structural transition of the $\operatorname{MoPrP}(121-$ 231) fragment in the experimental buffer is $68{ }^{\circ} \mathrm{C}$ (Figure $4 \mathrm{a}$ and Table 1). The $T_{\mathrm{m}}$ values of the full-length protein and the fragment are comparable, indicating that the presence of a large number of positive charges in the full-length protein does not affect the stability of the structured region of the prion protein. Sodium sulfate at concentrations $<0.1$ $\mathrm{M}$ is without any effect on $T_{\mathrm{m}}$. Higher concentrations $(0.25$ and $0.5 \mathrm{M}$ ) marginally increase the stability of the protein fragment (Figure 4a). Similar behavior has also been observed in $0.5 \mathrm{M}$ sodium fluoride solution (Table 1).
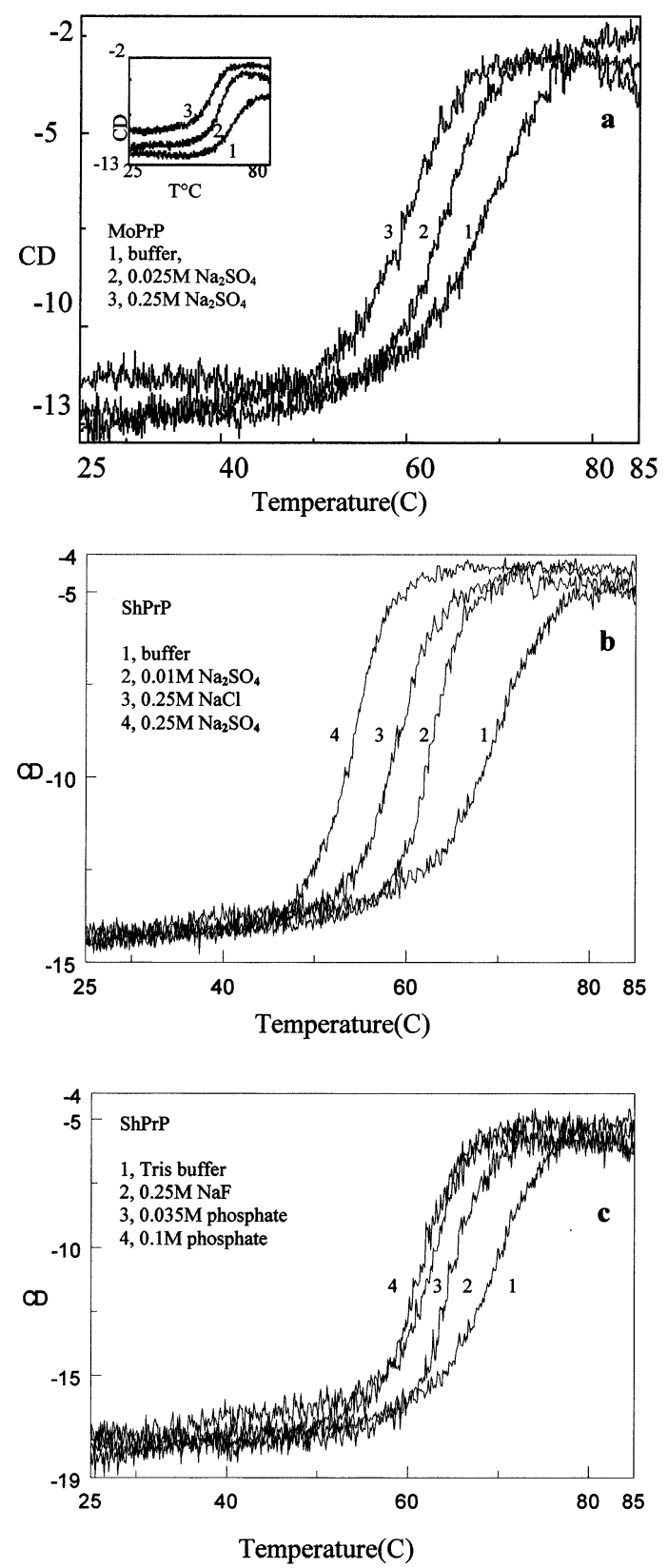

FIGURE 2: Thermal denaturation of (a) the full-length mouse prion protein and (b and c) the sheep prion protein, in buffer and in the presence of different salts. The CD unit is millidegrees. The temperature, $T_{\mathrm{m}}$, where $50 \%$ of the protein becomes unfolded has been calculated from the structural transition curve using the JASCO protein denaturation program. In the inset of (a), thermal denaturation profiles of the proteins in buffer and $\mathrm{Na}_{2} \mathrm{SO}_{4}$ solutions are shown. $T_{\mathrm{m}}$ values were calculated on the basis of these curves. Since the initial and final $C D$ values in different solutions varied (Figure 1a), for uniform presentation of the results, the denaturation curves are normalized here and in subsequent figures using a program of JASCO which presents the results making initial and final CD values comparable without changing the $T_{\mathrm{m}}$ values. The $T_{\mathrm{m}}$ values (in parentheses) are (a) $1,0.1 \mathrm{M}$ Tris buffer $\left(70{ }^{\circ} \mathrm{C}\right), 2,0.025 \mathrm{M}$ $\mathrm{Na}_{2} \mathrm{SO}_{4}\left(66^{\circ} \mathrm{C}\right)$, and $3,0.25 \mathrm{M} \mathrm{Na}_{2} \mathrm{SO}_{4}\left(60^{\circ} \mathrm{C}\right)$. The $T_{\mathrm{m}}$ values in (b) are 1 , buffer $\left(70{ }^{\circ} \mathrm{C}\right), 2,0.01 \mathrm{M} \mathrm{Na}_{2} \mathrm{SO}_{4}\left(63{ }^{\circ} \mathrm{C}\right), 3,0.25 \mathrm{M}$ $\mathrm{NaCl}\left(59^{\circ} \mathrm{C}\right)$, and $4,0.25 \mathrm{M} \mathrm{Na}_{2} \mathrm{SO}_{4}\left(55^{\circ} \mathrm{C}\right)$. The $T_{\mathrm{m}}$ values in (c) are 1 , Tris buffer $\left(70{ }^{\circ} \mathrm{C}\right), 2,0.25 \mathrm{M} \mathrm{NaF}\left(65^{\circ} \mathrm{C}\right)$, and 3 and 4 , $0.035 \mathrm{M}\left(63{ }^{\circ} \mathrm{C}\right)$ and $0.1 \mathrm{M}\left(61^{\circ} \mathrm{C}\right)$ sodium phosphate buffer, $\mathrm{pH}$ 7.5. In $0.2 \mathrm{M}$ Tris buffer the $T_{\mathrm{m}}$ value for sheep protein is $68^{\circ} \mathrm{C}$, indicating that the ionic strength of the buffer does not influence the denaturation property of the protein significantly. All $T_{\mathrm{m}}$ values are the average of two determinations. 
Table 1: Comparison of the Temperature of the Midpoint of the Structural Transition, $T_{\mathrm{m}}\left({ }^{\circ} \mathrm{C}\right)$, of the Full-Length Prion Proteins, the $\mathrm{C}-$ Terminal Fragment, and Lysozyme in Salt Solutions

\begin{tabular}{|c|c|c|c|c|}
\hline \multirow[b]{2}{*}{ salt (M) } & \multicolumn{4}{|c|}{$T_{\mathrm{m}}\left({ }^{\circ} \mathrm{C}\right)$} \\
\hline & ShPrP & MoPrP & $\begin{array}{c}\text { MoPrP } \\
121-231\end{array}$ & lysozyme \\
\hline \multicolumn{5}{|l|}{ buffer $^{a}$} \\
\hline 0.1 & 70 & 70 & 68 & 75 \\
\hline \multicolumn{5}{|l|}{$\mathrm{Na}_{2} \mathrm{SO}_{4}$} \\
\hline 0.01 & 63 & 67 & & \\
\hline 0.25 & 55 & 60 & 68 & 76 \\
\hline 0.5 & $b$ & $b$ & 71 & 78 \\
\hline \multicolumn{5}{|l|}{$\mathrm{NaCl}$} \\
\hline 0.025 & 64 & 68 & 68 & 75 \\
\hline 0.25 & 59 & 65 & 68 & 75 \\
\hline \multicolumn{5}{|l|}{$\mathrm{NaF}$} \\
\hline 0.25 & 65 & 68 & 70 & 76 \\
\hline \multicolumn{5}{|l|}{$\mathrm{Na}_{2} \mathrm{HPO}_{4}$} \\
\hline 0.1 & 61 & 65 & 70 & 76 \\
\hline \multicolumn{5}{|l|}{$\mathrm{NaClO}_{4}$} \\
\hline 0.5 & $b$ & $b$ & 63 & 67 \\
\hline
\end{tabular}

${ }^{a}$ Tris- $\mathrm{HCl}, \mathrm{pH} 7.5$; all salt solutions were in this buffer except $\mathrm{Na}_{2} \mathrm{HPO}_{4}$ (pH 7.5). ${ }^{b}$ Precipitation.

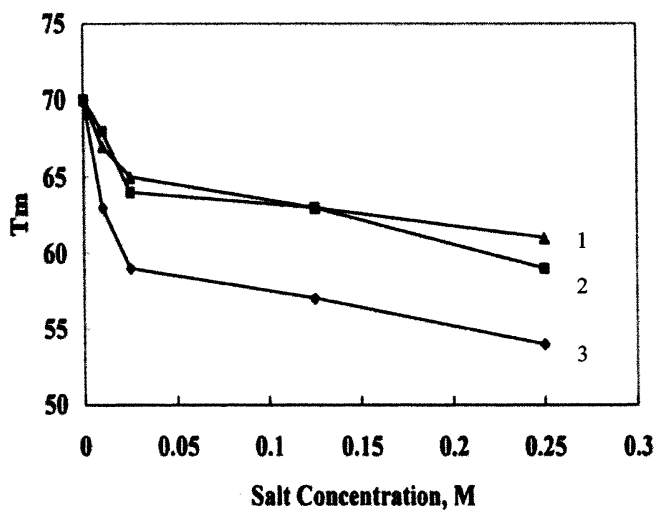

FIGURE 3: Variation of temperature of the midpoint of thermal denaturation, $T_{\mathrm{m}}$, of prion proteins in salt solutions: 1 and 3 , sheep prion protein in $\mathrm{NaCl}$ and $\mathrm{Na}_{2} \mathrm{SO}_{4}$ solutions, respectively, and 2, mouse protein in $\mathrm{Na}_{2} \mathrm{SO}_{4}$.

Sodium chloride $(0.5 \mathrm{M})$ is without any effect on the thermal stability of the protein fragment (Table 1) whereas $\mathrm{NaClO}_{4}$ solution destabilizes its structure as is evidenced from the lowering of the $T_{\mathrm{m}}$ value to $63{ }^{\circ} \mathrm{C}$ in $0.5 \mathrm{M}$ salt solution (Figure 4). The results demonstrate that the prion protein fragment in the presence of salt shows stabilization properties different from that of the full-length prion protein.

We have investigated the effects of the above salts on the thermal stability of lysozyme to compare the results with those of prion proteins under the same solution conditions. The results show that there is an increase of the $T_{\mathrm{m}}$ value from $75{ }^{\circ} \mathrm{C}$ in buffer to $78{ }^{\circ} \mathrm{C}$ in $0.25 \mathrm{M} \mathrm{Na}_{2} \mathrm{SO}_{4}$ solution (Figure $4 \mathrm{~b}$ ). The $T_{\mathrm{m}}$ value increases marginally in $0.5 \mathrm{M}$ $\mathrm{NaCl}$ (not shown) compared to that in buffer whereas the same concentration of $\mathrm{NaClO}_{4}$ decreases the $T_{\mathrm{m}}$ values to $67^{\circ} \mathrm{C}$. This shows that sulfate ion stabilizes lysozyme against thermal denaturation and chloride ion does not affect the stability of the protein whereas perchlorate ion destabilizes the structure of lysozyme. All proteins studied in the literature behave similarly to lysozyme, which is also observed with the prion protein fragment (38). The $T_{\mathrm{m}}$ values of all the proteins in different salt solutions have been summarized in Table 1.
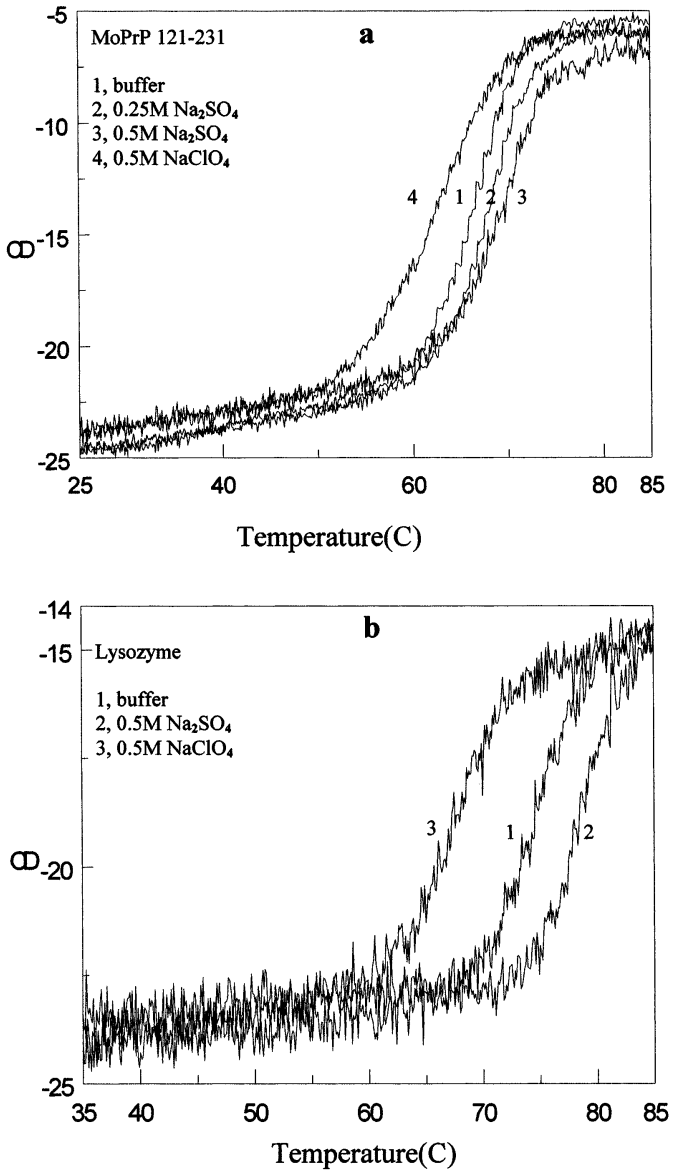

FIGURE 4: Thermal denaturation of (a) the C-terminal mouse prion protein fragment 121-231 and (b) lysozyme, in different salt solutions. The CD unit is millidegrees. The $T_{\mathrm{m}}$ values (in parentheses) in (a) are 1 , buffer $\left(68^{\circ} \mathrm{C}\right), 2,0.25 \mathrm{M}$ sodium sulfate $\left(68^{\circ} \mathrm{C}\right), 3$, $0.5 \mathrm{M}$ sodium sulfate $\left(71^{\circ} \mathrm{C}\right)$, and $4,0.5 \mathrm{M}$ sodium perchlorate $\left(63{ }^{\circ} \mathrm{C}\right)$. (b) The $T_{\mathrm{m}}$ values for lysozyme are 1 , buffer $\left(75^{\circ} \mathrm{C}\right), 2$, $0.5 \mathrm{M}$ sodium sulfate $\left(78^{\circ} \mathrm{C}\right)$, and $3,0.5 \mathrm{M}$ sodium perchlorate $\left(67^{\circ} \mathrm{C}\right)$. For lysozyme, the thermal transitions were monitored until $88^{\circ} \mathrm{C}$ where all samples attained $\mathrm{CD}$ plateau values. For uniformity of presentation the transitions are shown until $85^{\circ} \mathrm{C}$.

Tryptophan Fluorescence. Both the full-length mouse and sheep recombinant proteins show a fluorescence maximum around $350 \mathrm{~nm}$ when excited at $280 \mathrm{~nm}$ which arises mostly from the solvent-exposed tryptophans of the octapeptide repeats and tryptophan at the 148 position in the mouse protein (sheep protein has tyrosine at this position). A nonlinear decrease in the fluorescence intensity is observed. At 0.095 $\mathrm{M}$ sodium sulfate concentrations, the maximum used in this study, the fluorescence quenching values are $\sim 25 \%$ and $\sim 50 \%$ for mouse and sheep prion protein, respectively (Figure 5). The extent of fluorescence quenching in $\mathrm{NaCl}$ is less than that in sulfate. The fluorescence intensity of $\mathrm{N}$-acetyltryptophan ethyl ester, used as a control, is not significantly affected by salt; for example, there is only an $\sim 5 \%$ decrease in tryptophan fluorescence quenching in $0.095 \mathrm{M} \mathrm{Na}_{2} \mathrm{SO}_{4}$. In all of the above experiments, the changes in the fluorescence intensities did not accompany any change in the tryptophan emission maxima of the proteins or the peptide.

\section{DISCUSSION}

Salt solutions have large effects on the structure and properties of proteins, including their solubility, denaturation, 


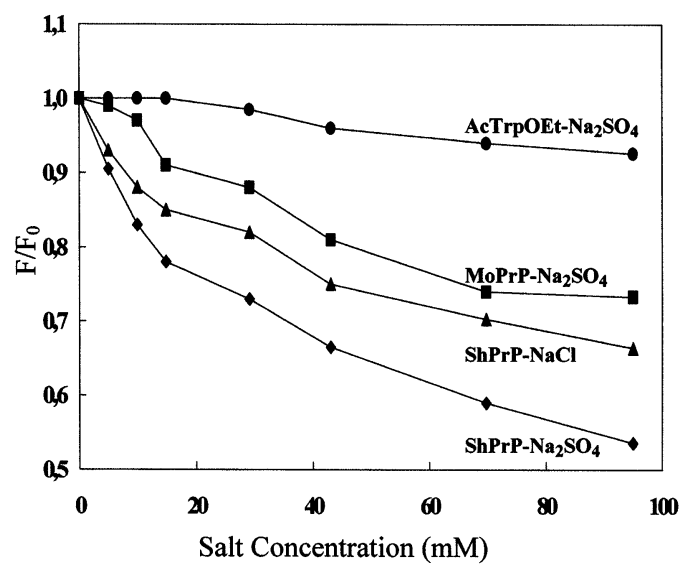

FIGURE 5: Quenching of tryptophan fluorescence by increasing concentrations of sodium sulfate and sodium chloride. From top to bottom, $N$-acetyltryptophan ethyl ester $(5 \mu \mathrm{M})$ and full-length mouse prion protein $(0.5 \mu \mathrm{M})$ in $\mathrm{Na}_{2} \mathrm{SO}_{4}$ and sheep prion protein $(0.5 \mu \mathrm{M})$ in the presence of $\mathrm{NaCl}$ and $\mathrm{Na}_{2} \mathrm{SO}_{4}$, respectively. Temperature $=$ $20{ }^{\circ} \mathrm{C}$.

dissociation into subunits, and the activity of the enzymes. These effects are sensitive to the nature of the salt and may vary over a wide range, even for the salts of the same type. The order of effectiveness of different salts on proteins is generally similar to the Hofmeister series which was described for the salting out of the proteins more than a century ago (37).

The effect of salt on the structural stability of proteins (both acidic and basic) becomes important at moderate salt concentrations $(0.01-1.0 \mathrm{M})$ at neutral $\mathrm{pH}$, and the effect is dominated by the anions (37). The stability of the protein against denaturation follows the Hofmeister series: sulfate (phosphate) $>$ fluoride $>$ chloride $>$ bromide $>$ iodide (perchlorate) $>$ thiocyanate. Interestingly, this is also the order in which these ions elute from a Sephadex G-10 column (37). The ions preceding chloride are polar kosmotropes, polar water-structure makers, and stabilize protein against denaturation whereas those following it, waterstructure breaker ions, destabilize, i.e., denature proteins. The chloride ion in the concentration range of $0.1-0.7 \mathrm{M}$ has little effect on protein stability (37). A considerable amount of studies on the effects of salts on the structural properties of proteins have been carried out in the past which suggest that at least two effects of salt, viz., their effects on solvent (water) structure and electrostatic interaction with the charged groups of the protein, make major contributions to the structure-stabilizing properties of the proteins $(38-42)$.

The Hofmeister anions which stabilize protein structure, viz., $\mathrm{SO}_{4}{ }^{2-}, \mathrm{PO}_{4}{ }^{2-}$, and $\mathrm{F}^{-}$, destabilize both full-length mouse and sheep prion proteins. The lowering of the $T_{\mathrm{m}}$ values for both of the proteins in phosphate buffer compared to Tris buffer also shows that phosphate, like sulfate and fluoride, destabilizes the prion proteins. The mouse and sheep prion proteins are basic, having $\mathrm{p} I$ values 11.2 and 11.7, respectively. However, lysozyme $(\mathrm{p} I$ 10.7) and the C-terminal 121-231 protein fragment $(\mathrm{p} I 6.7)$, containing the ordered region of the prion protein, follow Hofmeister behavior. Lysozyme and the prion protein fragment show marginal increase in their secondary structural contents, similar to the recently studied staphylococal nucleases $(\mathrm{p} I \mathrm{~s}>9)$ in $\mathrm{Na}_{2}-$ $\mathrm{SO}_{4}$ solution. The structural stability of these nucleases also increases in the presence of sulfate (38). It needs to be mentioned that anions do not follow the Hofmeister series on the folding of positively charged proteins induced by these ions (41). Further, all ions, whether structure stabilizing or destabilizing, have been reported to stabilize human serum albumin structure, preventing intermediate formation during urea-induced denaturation of the protein (43).

The stability of the above nucleases in the presence of Hofmeister anions has been suggested to arise from the decreased level of intramolecular electrostatic repulsion due to binding of anions to the positive charges present in the protein (38). However, the effect of $\mathrm{NaClO}_{4}$, which destabilizes lysozyme and all other proteins studied in the literature, cannot be explained by the anion binding to the positive charges of the proteins $(44-48)$. A comparison of the $T_{\mathrm{m}}$ values of the sheep prion protein in the same molar concentrations $(0.25 \mathrm{M})$ of $\mathrm{NaF}\left(T_{\mathrm{m}} 65^{\circ} \mathrm{C}\right)$ and $\mathrm{NaCl}$ solutions $\left(T_{\mathrm{m}} 59^{\circ} \mathrm{C}\right)$ also suggests that simple electrostatic interaction between the anions and the full-length prion protein is not responsible for the observed destabilization. Despite the fact that the study of proteins in salt solutions is nearly a century old, no theory has been able to satisfactorily explain the stabilization/destabilization properties of the proteins in salt solutions $(37,38)$. It is considered that increased hydrophobic interaction resulting from the modification of the solvent water structure by the stabilizing Hofmeister kosmotropic anions (for example, sulfate, phosphate, fluoride) prevents protein denaturation, and contrary to this, the chaotropic perchlorate ion by breaking the water structure decreases hydrophobic interaction in the protein and, together with its favorable interaction with the peptide group, denatures the protein $(37,44-46)$. The above explanations of stabilization and destabilization used for protein molecules can explain properties of the prion protein 121-231 (MoPrP) fragment and lysozyme in different salt solutions. It has also been suggested that the interaction of proteins with stabilizing ions involves preferential hydration, that is, exclusion of the ions from the vicinity of the surface of the protein which increases the stability of the protein $(38,47-50)$.

The unfolding of the full-length prion proteins in the presence of protein structure stabilizing ions cannot be explained on the basis of the above considerations. Comparison of the results of the full-length $\operatorname{MoPrP}(23-231)$ and its C-terminal fragment $\operatorname{MoPrP}(121-231)$ shows that the presence of the unstructured part $(23-129)$ of the full-length prion protein influences the structural property of the fulllength molecule, giving the prion protein its characteristic properties of destabilization in salt solutions. The N-terminal segment 23-129 amino acid residues of prion protein are considerably rich in glycine groups, and quite often they are present consecutively as parts of the four octapeptide repeats (Appendix) and determine the biological function of the prion protein $(21,22,28)$. A comparison of amino acid sequences shows that 31 of the 37 and 35 of the 40 glycine groups of mouse and sheep prion proteins, respectively, are present in the unstructured segment (Appendix). The results in the literature suggest that the glycine group has unfavorable interaction with solvent water, and its favorable or unfavorable interaction with a solute most probably determines whether a particular protein will be denatured or stabilized by the solute $(49,50)$. The solubility values of compounds with an increasing number of glycine groups, viz., carboben- 


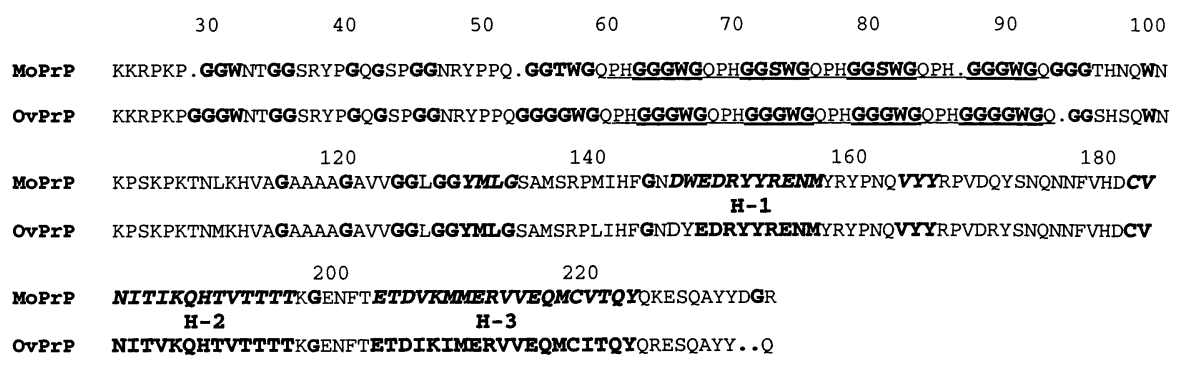

FIGURE 6: Amino acid sequence of murine (Mo) and sheep (Ov) prion proteins (aligned).

zoxyglycine, diglycine, and triglycine amides in water, are $9.5,4.5$, and $1.2 \mathrm{mM}$, respectively (51). Calculation of the free energy values from these data shows that addition of one more glycine group to the carbobenzoxyglycine makes it unfavorable in water by $440 \mathrm{cal} / \mathrm{mol}$, which becomes further unfavorable by $780 \mathrm{cal} / \mathrm{mol}$ when the molecule contains the third glycine group, indicating that interaction of water with the glycine groups is not energetically favorable $(50,51)$. This is also borne out from the extremely low solubility of the polyglycines, which are a small fraction of the chain lengths of protein in water, which also shows that interaction of polyglycine with the aqueous milieu is equivalent to interaction with the peptide backbone (50).

It is known that anions, whether protein stabilizing or destabilizing, interact favorably with the glycine group, making this group energetically more favorable in salt solutions compared to water $(44,46)$. The favorable interaction can arise either from a stoichiometric ion-dipole complex or from clustering of ions in the vicinity of the amide dipole of the glycyl group $(51,52)$. Among the ions studied here, the sulfate ion $(<0.25 \mathrm{M})$ interacts most strongly with the amide dipole (44). This is most probably reflected from the quenching of the solvent-exposed tryptophan fluorescence of the proteins in the vicinity of glycine groups. The results in Figure 5 show that both $\mathrm{Na}_{2} \mathrm{SO}_{4}$ and $\mathrm{NaCl}$ can quench tryptophan fluorescence of the mouse and sheep prion proteins. The quenching effects on protein tryptophans are considerably more pronounced than the quenching observed for tryptophan of $N$-acetyltryptophan ethyl ester. The observed effect of salts on the Trp fluorescence quenching of the full-length protein could arise most likely from the anion-induced conformational change in the $\mathrm{N}$-terminal region which affects the environment/properties of the Trp groups situated in this segment. The observed tryptophan fluorescence differences may also result from the increase in the local anion concentration (due to ion-dipole complex or ion clustering, see above) around glycine groups, thereby effectively quenching the fluorescence of tryptophan in their vicinity. The increase in the number of consecutive glycine groups in the peptides increases their favorable interactions with the anions (44). This is probably reflected in the higher tryptophan quenching values of the sheep prion protein by sodium sulfate compared to the mouse protein containing a relatively smaller number of glycine residues in the neighborhood of tryptophans (Appendix).

The exclusion of ions from the surface of the protein, which increases preferential hydration of protein, leads to its structural stability (48). Contrary to this, we consider that the presence of an increased number of anions on the prion protein surface due to their favorable interaction with the glycine groups present in the unstructured $\mathrm{N}$-terminal favors structural destabilization of the full-length prion protein in salt solutions. The favorable interaction of ions increases with the increase in the number of glycine groups, which probably explains the increased destabilization of the sheep prion protein having a greater number of glycine groups than the mouse protein in the $\mathrm{N}$-terminal segment. The low stabilizing energy of helix 1 (enthalpy value of $<20 \mathrm{kcal} / \mathrm{mol}$ compared to a value of $>50 \mathrm{kcal} / \mathrm{mol}$ for control $\alpha$-helices) probably makes it susceptible for destabilization as a consequence of increased ionic concentrations of bound anions at the $\mathrm{N}$-terminal segment of the full-length protein (19). From our results with $\operatorname{MoPrP}(121-231)$, it is also to be noted that the two internal salt bridges (D144-R148 and D147-R151), which predominantly stabilize the structure of prion protein helix 1, DWEDRYYREN (residues 144-154), are not affected by anions, further suggesting the influence of the glycine groups in the unstructured region whose interaction with the ions destabilizes the structure of the full-length protein in salt solutions (19). Our present result is also an example where small ions by preferential interaction to a protein at its unstructured N-terminal part signals conformational changes in the structured region of the protein situated at a distance from the site of interaction. Similar instances are known for protein-protein and protein-nucleic acid interactions which produce conformational signal transduction at a substantial distance from the sites of interaction of the molecules (53). However, a detailed study of the behavior of prion protein in various salt solutions in different environmental conditions, viz., $\mathrm{pH}$, would be useful for understanding the process of unfolding of the molecule. It is known that proteins can undergo denaturation through stable intermediate(s) in the presence of various denaturants including salt solutions. The present result of the destabilization of the prion protein by anions could also account for an anion-induced conformational change to a partially folded intermediate. In the present study we have not addressed whether the observed effects of salts on prion protein result in denaturation or formation of partially unfolded intermediate conformation(s). Our CD results indicate that a considerable amount of nativelike secondary structure is still retained in the full-length prion proteins in salt solutions where its native structure is destabilized. Studies on the tertiary structure of the protein in salt solutions would be useful to characterize the process of destabilization of the prion protein in these solutions.

Understanding the processes of cellular prion protein unfolding and its refolding to the polymeric scrapie isoform is of paramount importance (54). The conformational transition from the $\alpha$-helical cellular $\operatorname{PrP}^{\mathrm{C}}$ to the $\beta$-sheet-rich scrapie $\mathrm{PrP}^{\mathrm{Pc}}$ isoform is separated by a large energetic barrier that is associated with protein unfolding (36). Pentosan 
sulfate, a sulfated glycosaminoglycan, has been shown to induce the formation of the scrapie isoform from hamster prion protein (24). DNA induces conversion of recombinant prion protein to the scrapie isoform, and the interaction leads to amyloid formation $(23,25)$. On the basis of our present results, it can be suggested that interaction of the anions (sulfate/phosphate) of these polyionic ligands with prion protein could induce unfolding of the prion protein. A large number of studies in the literature show that unfolding of a protein molecule that allows their intermolecular association through noncovalent interaction would lead to oligomerization and subsequent polymerization to amyloid $(36,55)$. The polyanions, similar to the anions studied here, can be expected to unfold prion protein in a proper environment and could result in ordered amyloids depending on the extent of protein unfolding. It is expected that the organic components of the polyanions would also play a role in the process of unfolding to induce $\mathrm{PrP}^{\mathrm{Sc}}$ and amyloid formation (23-25).

\section{ACKNOWLEDGMENT}

P.K.N. thanks Prof. R. Glockshuber, ETH, Zurich, for providing the mouse prion protein and its C-terminal fragment and Dr. C. Craescu, Institut Curie, Orsay, for facilities. He also thanks the reviewers for their critical comments and suggestions.

\section{APPENDIX}

The amino acid sequences of murine (Mo) and sheep (Ov) prion proteins (aligned) are shown in Figure 6. Only the amino acid sequences of the mature proteins are shown. The glycine and tryptophan residues are shown in bold; the four octapeptide repeats between residues 61 and 93 are underlined. The three $\alpha$-helices are shown in italics and numbered as $\mathrm{H}-1, \mathrm{H}-2$, and $\mathrm{H}-3$, respectively, corresponding to helices 1,2 , and $3(9)$. $\beta$-Strands $128-131$ and $164-167$ are also shown in italics. The three-dimensional structure of sheep prion protein has not been determined. However, the NMR structures of bovine and human prion proteins show similar secondary structures as in the mouse protein spanning nearly the same residues (in these, the third helix is longer by 9 amino acids at the C-terminal end) (13). Therefore, the sheep prion protein is expected to have a secondary structure similar to those of the other prion proteins. The important point of Figure 6 is to show the differences in the glycine compositions of the two proteins. Trp 32, Trp 58, Trp 66, and Trp 91 (the latter two belong to the first and fourth octapeptide repeats, respectively) have respectively $2,2,3$, and 3 consecutive glycyl groups in the mouse prion protein compared to $3,4,3$, and 4 in the sheep prion protein. In addition, Trp 74 and Trp 82 (in the second and third octapeptide repeats, respectively) are preceded by three consecutive glycine groups in the sheep protein. In mouse prion protein, these tryptophans are preceded by GGS sequences.

\section{REFERENCES}

1. Prusiner, S. B. (1998) Prions, Proc. Natl. Acad. Sci. U.S.A. 95, 13363-13383.

2. Caughey, B. (2001) Interactions between prion protein isoforms: the kiss of death? Trends Biochem. Sci., 235-242.

3. Scott, M. R., Will, R., Ironside, J., Nguyen, H. B., Tremblay, P., DeArmond, S. J., and Prusiner, S. B. (1999) Compelling trans- genetic evidence for transmission of bovine spongiform encephalopathy prions to humans, Proc. Natl. Acad. Sci. U.S.A. 96, 15137-15142.

4. Rudd, P. M., Endo, T., Colominas, C., Groth, D., Wheeler, S. F., Harvey, D. J., Wormald, M. R., Serban, H., Prusiner, S. B., Kobata, A., and Dwek, R. A. (1999) Glycosylation differences between the normal and pathogenic prion protein isoforms, Proc. Natl. Acad. Sci. U.S.A. 96, 13044-13049.

5. Kelly, J. W. (1998) The alternative conformations of amyloidogenic proteins and their multi-step assembly pathways, Curr Opin. Struct. Biol. 8, 101-106.

6. Riek, R., Hornemann S., Wider, G., Glockshuber, R., and Wuthrich, K. (1997) NMR characterization of the full-length recombinant murine prion protein, $\operatorname{mPrP}(23-231)$, FEBS Lett. 413, 282-288.

7. Billeter, M., Riek, R., Wider, G., Hornemann, S., Glockshuber, R., and Wuthrich, K. (1997) Prion protein NMR structure and species barrier for prion protein, Proc. Natl. Acad. Sci. U.S.A. 94, 7281-7285.

8. Riek, R., Wider, G., Billeter, M., Hornemann, S., and Glockshuber, R. (1998) Prion protein NMR structure and familial human spongiform encephalopathies, Proc. Natl. Acad. Sci. U.S.A. 95, $11667-11172$.

9. Riek, R., Hornemann, S., Wider, G., Billeter, M., Glockshuber, R., and Wuthrich, K. (1996) NMR structure of the mouse prion protein domain PrP(121-231), Nature 382, 180-182.

10. Donne, D. G., Viles, J. H., Groth, D., Mehlhorn, I., James, T. L., Cohen, F. E., Prusiner, S. B., Wright, P. E., and Dyson, H. J. (1997) Structure of the recombinant full-length hamster prion protein $\operatorname{PrP}(29-231)$ : the N-terminus is highly flexible, Proc. Natl. Acad. Sci. U.S.A. 94, 13452-13457.

11. James, T. L., Liu, H., Ulyanov, N. B., Farr-Jones, S., Zhang, H., Donne, D. G., Kaneko, K., Groth, D., Mehlhorn, I., Prusiner, S. B., and Cohen, F. E. (1997) Solution structure of a 1423-residue recombinant prion protein corresponding to the infectious fragment of the scrapie isoform, Proc. Natl. Acad. Sci. U.S.A. 94, 1008610091.

12. Liu, H., Farr-Jones, S., Ulyanov, N. B., Llinas, M., Marqusse, S. Groth, D., Cohen, F. E., Prusiner, S. B., and James, T. L. (1999) Solution structure of Syrian hamster prion protein $\operatorname{rrP}(90-231)$, Biochemistry 38, 5362-5377.

13. Garcia, F. L., Zahn, R., Riek, R., and Wuthrich, K. (2000) NMR structure of the bovine prion protein, Proc. Natl. Acad. Sci. U.S.A. 97, 8334-8339.

14. Glockshuber, R. (2001) Folding dynamics and energetics of recombinant prion proteins, Adv. Protein Chem. 57, 83-105.

15. Wuthrich, K., and Riek, R. (2001) Three-dimensional structures of prion proteins, Adv. Protein Chem. 57, 55-82.

16. Knaus, K. J., Morillas, M., Sweitnicki, W., Malone, M., Surewicz, W. K., and Yee, V. C. (2001) Crystal structure of the human prion protein reveals a mechanism for oligomerization, Nat. Struct Biol. 8, 770-774.

17. Viles, J. H., Cohen, F. E., Prusiner, S. B., Goodin, D. B., Wright, P. E., and Dyson, J. (1999) Copper binding to the prion protein: Structural implications of four identical cooperative binding sites, Proc. Natl. Acad. Sci. U.S.A. 96, 2042-2047.

18. Quaglio, E., Chiesa, R., and Harris, D. A. (2001) Copper Converts the Cellular Prion Protein into a Protease-resistant Species That Is Distinct from the Scrapie Isoform, J. Biol. Chem. 276, 1143211438.

19. Morrissey, M. P., and Shakhnovich, E. I. (1999) Evidence for the role of $\operatorname{PrP}(\mathrm{C})$ helix 1 in the hydrophilic seeding of prion aggregates, Proc. Natl. Acad. Sci. U.S.A. 96, 11293-11298.

20. Zuegg, J., and Gready, J. E. (1999) Molecular dynamics simulations of human prion protein: importance of correct treatment of electrostatic interactions, Biochemistry 38, 13862-13876.

21. Brockes, J. (1999) Topics in prion cell biology, Curr. Opin. Neurobiol. 5, 571-577.

22. Mouillet-Richard, S., Ermonval, M., Chebassier, C., Laplanche, J. L., Lehmann, S., Launay, J. M., and Kellermann, O. (2000) Signal Transduction Through Prion Protein, Science 289, 19251928.

23. Nandi, P. K., and Leclerc, E. (1999) Polymerization of murine recombinant prion protein in nucleic acid solution, Arch. Virol. $144,1751-1763$

24. Wong, C., Xiong, L.-W., Horiuchi, M., Raymond, L., Wehrly, K., Chesebro, B., and Caughey, B. (2001) Sulfated glycans and elevated temperature stimulate $\mathrm{PrP}^{\mathrm{Sc}}$-dependent cell-free formation of protease-resistant prion protein, EMBO J. 20, 377-386. 
25. Cordeiro, Y., Machado, F., Juliano, L., Juliano, M. A., Brentani, R. R., Foguel, D., and Silva, J. L. (2001) DNA converts cellular prion protein into the $\beta$-sheet conformation and inhibits prion peptide aggregation, J. Biol. Chem. 276, 49400-49409.

26. Nandi, P. K., and Sizaret, P. (2001) Murine recombinant prion protein induces ordered aggregation of linear nucleic acids to condensed globular structures, Arch. Virol. 146, 327-345.

27. Gabus, C., Auxilien, S., Péchoux, Dormont, D., Swietnicki, W., Morillas, M., Surewitz, W., Nandi, P., and Darlix, J. L. (2001) The prion protein has DNA strand transfer properties similar to retroviral nucleocapsid protein, J. Mol. Biol. 307, 1011-1021.

28. Gabus, C., Derrington, E., Leblanc, P., Chnaiderman, J., Dormont, D., Sweitnicki, W., Morillas, M., Surewicz, W., Marc, D., Nandi, P., and Darlix, J. L. (2001) The prion protein has RNA binding and chaperoning properties characteristic of nucleocapsid protein NCP7 of HIV-1, J. Biol. Chem. 276, 19301-19309.

29. Swietnicki, W., Petersen, R. B., Gambetti, P., and Surewicz, W. K. (1997) pH-dependent Stability and Conformation of the Recombinant Human Prion Protein PrP(90-231), J. Biol. Chem. 272, 27517-27520.

30. Swietnicki, W., Petersen, R. B., Gambetti, P., and Surewicz, W. K. (1998) Familial mutations and the thermodynamic stability of the recombinant human prion protein, J. Biol. Chem. 273, 3104831052 .

31. Liemann, S., and Glockshuber, R. (1999) Influence of amino acid substitutions related to inherited human prion diseases on the thermodynamic stability of the cellular prion protein, Biochemistry $38,3258-3267$.

32. Hornemann, S., and Glockshuber, R. (1998) A scrapie-like unfolded intermediate of the prion protein domain $\operatorname{PrP}(121-231)$ induced by acid pH, Proc. Natl. Acad. Sci. U.S.A. 95, 60106014.

33. Wildegger, G., Liemann, S., and Glockshuber, R. (1999) Extremely rapid folding of the $\mathrm{C}$-terminal domain of the prion protein without kinetic intermediates, Nat. Struct. Biol. 6, 550-553.

34. Rezaei, H., Marc, D., Choiset, Y., Takahashi, M., Hoa, G. H. B. Haertle, T., Grosclaude, J., Debey, P. (2000) High yield purification and physicochemical properties of full-length recombinant allelic variants of sheep prion protein linked to scrapie susceptibility, Eur. J. Biochem. 267, 2833-2839.

35. Zanusso, G., Farinazzo, A., Fiorini, M., Gelati, M., Castagna, A., Righetti, P. G., Rizzuto, N., and Monaco, S. (2001) pH-dependent prion protein conformation in classical Creutzfeldt-Jakob disease, J. Biol. Chem. 276, 40377-40380.

36. Baskakov, I. V., Legname, G., Prusiner, S. B., and Cohen, F. E. (2001) Folding of prion protein to its native $\alpha$-helical conformation is under kinetic control, J. Biol. Chem. 276, 19687-19690.

37. Collins, K. D., and Washabaugh, M. W. (1985) The Hofmeister effect and the behaviour of water at interfaces, Q. Rev. Biophys. 18, 323-422

38. Nishimura, C., Uversky, V. N., and Fink, A. L. (2001) Effect of salts on the stability and folding of staphylococcal nuclease, Biochemistry 40, 2113-2128.

39. Booth, D. R., Sunde, M., Belloti, V., Robinson, C. V., Hutchinson, W. L., Fraser, P. E., Hawkins, P. N., Dobson, C. M., Radford, S. E., Blake, C. C., and Pepys, M. B. (1997) Instability, unfolding and aggregation of human lysozyme variants underlying amyloid fibrillogenesis, Nature 385, 787-793.

40. Goto, Y., and Fink, A. L. (1989) Conformational states of $\beta$-lactamase: molten-globule states at acidic and alkaline $\mathrm{pH}$ with high salt, Biochemistry 28, 945-952.

41. Goto, Y., Takahashi, N., and Fink, A. L. (1990) Mechanism of acid-induced folding of Proteins, Biochemistry 29, 3480-3488.

42. Yang, A. S., and Honig, B. (1994) Structural origins of $\mathrm{pH}$ and ionic strength effects on protein stability, acid denaturation of sperm whale myoglobin, J. Mol. Biol. 237, 602-614.

43. Muzammil, S., Kumar, Y., and Tayyab, S. (2000) Anion-induced stabilization of human serum albumin prevents the formation of intermediate during urea denaturation, Proteins 40, 29-38.

44. Nandi, P. K., and Robinson, D. R. (1972) The effects of salts on the free energy of the peptide group, J. Am. Chem. Soc. 94, 12991308.

45. von Hippel, P. H. (1975) Neutral salt effects on the conformational stability of biological macromlecules, in Protein-Ligand Interactions (Sund, H., and Blauer, G., Eds.) pp 452-471, Walter de Gruyter, NewYork.

46. Smith, J. S., and Scholtz, J. M. (1996) Guanidine hydrochloride unfolding of peptide helices: separation of denaturant and salt effects, Biochemistry 35, 7292-7297.

47. Kendrick, B. S., Chang, B. S., Arakawa, T., Peterson, B. Randolph, T. W., and Carpenter, J. F. (1997) Preferential exclusion of sucrose from recombinant interleukin-1 receptor antagonist: role in restricted conformational mobility and compaction of native state, Proc. Natl. Acad. Sci. U.S.A. 94, 11917-11922.

48. Timasheff, S. N. (1993) The control of protein stability and association by weak interactions with water: how do solvents affect these processes? Annu. Rev. Biophys. Biomol. Struct. 22, 67-97.

49. Wang A., and Bolen, D. W. (1997) A naturally occurring protective system in urea rich cells: Mechanism of osmolyte protection of proteins against denaturation, Biochemistry 36, 9101-9108.

50. Qu, Y., Bolen, C. L., and Bolen, D. W. (1998) Osmolyte-driven contraction of a random coil protein, Proc. Natl. Acad. Sci. U.S.A. 95, 9268-9273.

51. Robinson, D. R., and Jencks, W. P. (1965) The effect of compounds of the urea-guanidine class on the activity coefficient of acetyl tetraglycine ethyl ester and related compounds, J. Am. Chem. Soc. 87, 2462-2470.

52. Jencks, W. P. (1969) Catalysis in Chemistry and Enzymology, pp 383-384, McGraw-Hill, New York.

53. Demchenko, A. P. (2001) Recognition between flexible protein molecules: induced and assisted folding, J. Mol. Recognit. 14, 42-61.

54. Chiti, F., Webster, P., Taddei, N., Clark, A., Stefani, M., Ramponi, G., and Dobson, C. M. (1999) Designing conditions for in vitro formation of amyloid protofilaments and fibrils, Proc. Natl. Acad. Sci. U.S.A. 96, 3590-3594.

55. Prusiner, S. B., Scott, M. R., DeArmond, S. J., and Cohen, F. E. (1998) Prion protein biology, Cell 93, 337-348. 